\title{
THE
}

2018

\section{Propensity to plan, financial capability, and financial satisfaction}

Jing Jian Xiao

University of Rhode Island, jjxiao@uri.edu

Barbara O'Neill

Follow this and additional works at: https://digitalcommons.uri.edu/hdf_facpubs

The University of Rhode Island Faculty have made this article openly available.

Please let us know how Open Access to this research benefits you.

This is a pre-publication author manuscript of the final, published article.

Terms of Use

This article is made available under the terms and conditions applicable towards Open Access Policy Articles, as set forth in our Terms of Use.

\section{Citation/Publisher Attribution}

Xiao, JJ, O'Neill, B. Propensity to plan, financial capability, and financial satisfaction. Int J Consum Stud. 2018; 42: 501- 512. https://doi.org/10.1111/ijcs.12461

Available at: https://doi.org/10.1111/ijcs.12461

This Article is brought to you for free and open access by the Human Development and Family Science at DigitalCommons@URI. It has been accepted for inclusion in Human Development and Family Science Faculty Publications by an authorized administrator of DigitalCommons@URI. For more information, please contact digitalcommons-group@uri.edu. 
Xiao, J. J., \& O'Neill, B. (2018). Propensity to plan, financial capability, and financial

satisfaction. International journal of consumer studies, 42(5), 501-512.

\title{
Propensity to Plan, Financial Capability, and Financial Satisfaction
}

\begin{abstract}
Propensity to plan is an indicator of financial capability that contributes to consumer financial well-being. Previous research has shown that propensity to plan is positively related to objective financial well-being but little research was found to examine its association with subjective financial well-being. Using financial satisfaction to measure subjective financial well-being, this study addressed this research gap and had three objectives: 1) to explore factors associated with propensity to plan, 2) to examine the association between propensity to plan and financial capability factors, and 3) to examine the association between propensity to plan and financial satisfaction. Using data from the 2015 U.S. National Financial Capability Study, the results showed socioeconomic differences in propensity to plan. The results suggest consumers with more economic resources had higher scores in propensity to plan. In addition, propensity to plan was positively associated with financial capability factors, suggesting financial planning is a desirable financial behavior. Finally, propensity to plan made unique contributions to financial satisfaction after controlling for socioeconomic and other financial capability factors.
\end{abstract}

Key words: financial behavior, financial capability, financial literacy, financial well-being, propensity to plan

\section{Introduction}

Financial satisfaction, a measure of subjective financial well-being, is an important component of general well-being (Diener \& Biswas-Diener, 2002). Most previous research has focused on effects of income and other financial factors on financial satisfaction (Plagnol, 2010; Vera-Toscano, Ateca-Amestoy, \& Serrano-Del-Rosal, 2006). Some researchers explored the association between financial behavior and financial satisfaction (Alsemgeest, 2015; Xiao, Chen, \& Chen, 2014). To encourage consumers to actively pursue financial security and freedom, more research is needed to explore which specific financial behaviors contribute to consumer financial satisfaction. Planning for long-term financial goals is such a desirable financial behavior, which is considered an indicator of consumer financial capability (Lusardi \& Mitchell, 2007).

Propensity to plan refers to a consumer's tendency to plan for long-term goals that may result in rational, goal-setting behavior (Ameriks, Caplin, \& Leahy, 2003). Previous research demonstrates that propensity to plan contributes to financial well-being (Ali, Rahman, \& Bakar, 2015; Ameriks et al., 2003; Khwaja, Silverman, Sloan, 
\& Wang, 2007; Lee \& Kim, 2016; Lusardi \& Mitchell, 2007; Lynch, Netemeyer, Spiller, \& Zammit, 2010; O’Neill, Xiao, \& Ensle, 2016). Most previous studies examined the construct of propensity to plan using samples with limited representativeness and only examined the association between propensity to plan and objective measures of financial well-being. To fill out the research gap, this study examined the association between propensity to plan and financial satisfaction, a subjective measure of financial well-being (Joo \& Grable, 2006). Specifically, this study had three objectives: to examine factors associated with propensity to plan, to examine associations between propensity to plan and other financial capability factors, and to examine the association between propensity to plan and financial satisfaction after controlling for socioeconomic and other financial capability factors.

Compared to previous research, unique contributions of this study include that it uses a large, national representative sample in the U.S. to examine the key concept, propensity to plan, in a comprehensive manner; it enriches the literature of financial capability by conducting detailed analyses to examine associations of propensity to plan, a financial capability indicator, with other financial capability factors, and it expands the literature of financial well-being by examining the association between propensity to plan and subjective financial well-being. The results of this study can help researchers and practitioners better understand the concept of propensity to plan and its association with other financial capability factors and financial satisfaction, and inform business professionals to develop effective strategies to better serve consumers.

\section{Previous Research and Hypotheses}

\section{The Concept of Propensity to Plan and Characteristics of Planners}

Based on psychological theories of planning (Ajzen, 1991; Gollwitzer, 1996, 1999), Ameriks et al. (2003) proposed the concept of propensity to plan and studied its association with wealth accumulation with a sample of teacher retirement plan participants. Based on this concept, propensity to plan is a skill possessed by some individuals. Individuals with high propensity to plan are rational, patient, risk-taking, and good at budgeting, controlling spending, and saving frequently. These predictions are supported by basic psychological research showing that planning is crucial to the achievement of long-term goals (Gollwitzer, 1996).

Later, this concept was used to guide studying associations between propensity to plan and a set of financial well-being indicators such as retirement savings with a sample of older adults in the Health and Retirement Study (Lusardi \& Mitchell, 2007), retirement savings and net worth with a national sample of the Survey of Consumer Finances (Lee and Kim, 2016), wealth and smoking of a sample from three states (Khwaja et al., 2007), 
credit scores with an online panel sample (Lynch et al., 2010), financial satisfaction with a sample of investment seminar participants in Malaysia (Ali et al., 2015), and financial and health behaviors among an online survey sample (O’Neill et al., 2016). In the 2015 U.S. National Financial Capability Study, over half (57\%) of the surveyed respondents claimed that they set long-term goals and strive to achieve them, and higher education and income respondents were more likely to be planners (Lin et al., 2016). Those with the highest education and income reported the highest frequency of financial goal-setting. A study by de Rubio (2015) found that a long planning horizon plays an important role in explaining household asset accumulation and financial security. Households with heads who are older, White, male, with more years of education, and married have higher odds of having a longer planning horizon. These empirical findings suggest that individuals with characteristics implying having higher levels of economic resources are more likely to plan their finances. Based on previous research, the following hypothesis is proposed:

Hypothesis 1: Individuals with characteristics implying having higher levels of economic resources are associated with higher levels of propensity to plan.

\section{Propensity to Plan and Financial Capability}

Based on the concept of propensity to plan (Ameriks et al., 2003), planning is considered as a skill of money management and an indicator of financial capability. Financial capability can be defined broadly to include financial knowledge, resources, access, and habits (Lin et al., 2016). In the research literature, financial capability and financial literacy are often used interchangeably. For example, some researchers focus on financial literacy and define financial literacy as people's ability to process economic information and make informed personal financial decisions (Lusardi \& Mitchell, 2014). Some refer financial literacy as both financial knowledge and application of financial knowledge (Huston 2010) or examine the association between financial knowledge and behavior (Robb \& Woodyard, 2011). Other researchers define financial capability based on financial behavior measures (Atkinson, McKay, Collard, \& Kempson, 2006). Financial capability is also considered to include access to financial resources for low income populations (Birkenmaier, Sherraden, \& Curley, 2013; Sherraden \& Grinstein-Weiss, 2015). In this

study, financial capability is defined as a consumer ability that is a skillful combination of financial knowledge and behavior, i.e., an ability to apply appropriate financial knowledge and perform desirable financial behaviors to achieve financial well-being (Xiao, Chen, \& Sun, 2015; Xiao \& O’Neill, 2016; Xiao \& Porto, 2017). 
Many studies used data from different countries to study financial literacy and capability (Agnew \& Cameron-Agnew, 2015; Nicolini, Cude, \& Chatterjee, 2013; Riitsalu \& Põder, 2016). Research shows that financial capability, financial literacy, and financial behavior are positively associated. For example, financial literacy contributes to saving behavior based on a sample in Zimbabwe (Murendo \& Mutsonziwa, 2017). Future planning and goal-setting are associated with various positive financial behaviors that are indicative of financial capability. The 2016 U. S. Savings Survey (Bryan, 2016), like previous versions of this annual study, found that people with a savings plan with specific goals save more successfully than those without a plan. The study found that people who are planners, goal-oriented, and careful about spending money are more likely than non-planners to make savings progress and have sufficient savings for emergencies and retirement. Lusardi and Mitchell (2008) studied the financial literacy of women and found that women who are less financially literate are also less likely to plan for retirement and be successful planners. Propensity to plan is also found to be positively associated with an array of desirable financial and health behaviors (O’Neill et al., 2016). Based on previous research, the following hypothesis is proposed:

Hypothesis 2: Propensity to plan is positively associated with financial capability factors.

\section{Propensity to Plan and Financial Satisfaction}

The concept of propensity to plan assumes that individuals with high propensities to plan would manage their finances well, accumulate more wealth, and achieve a higher level of financial well-being, compared to their counterparts with low planning tendencies (Ameriks et al., 2003). Financial well-being is a multifaceted concept that transcends both financial literacy and financial capability (Drever et al., 2015). The Consumer Financial Protection Bureau defined financial well-being by focusing on present and future financial security and freedom (CFPB, 2015). Consumer financial well-being can be measured by both objective and subjective indicators. Previous research shows that propensity to plan is associated with several indicators of objective financial well-being. Ameriks et al. (2003) found that planners may be more able to control their spending, and thereby accumulate wealth. Additional evidence of the positive impact of planning is found by Lusardi and Mitchell (2007) who studied the retirement preparation of two age cohorts at two points in time. Planners in both cohorts arrived close to retirement with much higher wealth levels and displayed higher financial literacy than non-planners, even after controlling for many sociodemographic factors. Two additional studies found propensity to plan is positively associated with wealth and retirement savings (Khwaja et al., 2007; Lee \& Kim, 2016). Propensity to plan is also found to be associated with 
increased credit scores demonstrated by a study by Lynch et al. (2010). Based on that study, a 1-point increase in propensity to plan (on a 6-point scale) was associated with a 15.3 point increase in credit worthiness score, holding all other predictor variables constant.

Financial planning and goal-setting are closely associated with financial well-being. A study of financial well-being by the Consumer Financial Protection Bureau (CFPB) included four main elements, one of which is being on track to meet financial goals, to measure financial well-being (Ratcliffe, 2015). The Center for Financial Services Innovation (CFSI) used several financial behavior measures, including planning behavior, to measure “financial health" (Gutman, Garon, Hogarth, \& Schneider, 2015; Financial Health Consumer Segments 2015). The CFSI study found that people who plan ahead for large, irregular expenses are 10 times more likely to be in a financially healthy segment than those who do not plan ahead (Report Reveals, 2015).

Financial satisfaction is a subjective measure of financial well-being (Joo \& Grable, 2006). Financial satisfaction is associated with life satisfaction (Michalos \& Orlando, 2006; Xiao, Tang, \& Shim, 2009). Previous research has examined several factors associated with financial satisfaction such as various income definitions (Hsieh, 2004), income sources (Ahn, Ateca-Amestoy, \& Ugidos, 2014), relative income (Vera-Toscano, AtecaAmestoy, \& Serrano-Del-Rosal, 2006), income adequacy (Grable, Cupples, Fernatt, \& Anderson, 2013), wealth (Hansen, Slagsvold, \& Moum, 2008), worker sector types (Ferrer-i-Carbonell \& Gërxhani, 2011), child rearing (Kageyama \& Matsuura, 2016), and financial capability (Xiao, Chen, \& Chen, 2014; Xiao \& Porto, 2017). No previous research specifically examined the association between financial planning and financial satisfaction except for one study that used a sample of investment seminar participants in Malaysia (Ali et al., 2015). Compared to that study, this study uniquely contributed to existing literature by using a larger nationally representative sample in the U.S. and examining socioeconomic characteristics of people with a propensity to plan, associations between propensity to plan and financial capability factors, and propensity to plan and financial satisfaction. Based on the above discussion, a final hypothesis is proposed:

Hypothesis 3: Propensity to plan is positively associated with financial satisfaction.

\section{Method}

Data 
Data used in this study were from the 2015 U. S. National Financial Capability Study (NFCS), commissioned by the Financial Industry Regulatory Authority (FINRA) Investor Education Foundation and conducted by Applied Research and Consulting LLC, which included 27,564 American adults (roughly 500 per state and the District of Columbia). Descriptive statistics and other background information about this data set can be found in Lin et al. (2016). The NFCS is a triennial survey, started in 2009, that has been widely used and validated as a representative sample of the American population by researchers in economics, business, consumer science, and other social science fields (e.g. Robb, Babiarz, Woodyard, \& Seay, 2015). In this study, the key variable is propensity to plan. From the sample 268 respondents who answered "don't know" and 136 respondents who answered "prefer not to say" for the question regarding propensity to plan were removed, which resulted in a sample size of 27,160 used for data analyses.

\section{Variables}

Table 1 presents specifications of the variables used in this study including the original wording of several variables. Following previous research (Xiao \& O’Neill 2016), financial capability variables included four indicators that were objective financial literacy, subjective financial literacy, desirable financial behavior, and perceived financial capability. Objective financial literacy is the quiz score of six financial knowledge questions ranging from 0 to 6 . Subjective financial literacy is a self-assessment of financial knowledge with a range of 1-7 (1=very low, 7=very high). Perceived financial capability is a self-assessment of money management ability with a range of 1-7 (1=very low, 7=very high). Desirable financial behavior is the number of positive financial behaviors performed and reported by the respondents with a range of $0-4$ ( $0=$ no behavior is performed, 4=all four behaviors are performed). Propensity to plan is also considered a desirable financial behavior. Because this is the focus of this study, it was treated as a separate variable, measured by a question regarding long term goal setting, which is new in the 2015 NFCS. The original question was worded "I set long term financial goals and strive to achieve them" on a scale of 1-strongly disagree to 7-strongly agree. Financial satisfaction is a 10-point scale variable (1= "Not at all satisfied," 10= "Extremely satisfied"). Several socioeconomic variables are also included in the analyses. More details of variable specifications are presented in Table 1.

\section{Data Analyses}


Both bivariate and multivariate analyses were conducted to test the three hypotheses. Specifically, oneway ANOVA and an OLS linear regression were used to test H1 and correlations and OLS regressions were used to test $\mathrm{H} 2$ and $\mathrm{H} 3$. All analyses were conducted using the software of SPSS.

\section{Results}

\section{Factors Associated with Propensity to Plan}

Table 2 presents results of one-way ANOVA to examine socioeconomic differences in propensity to plan. On a 7-point scale, the mean score of propensity to plan in the whole sample was 4.86. Almost all socioeconomic characteristics differed statistically $(p<.05)$ in propensity to plan except for one, student loan holding. For demographic variables, respondents who were male, nonwhite, married, with dependent children, or working had higher scores in propensity to plan. Age showed a U-shape with the middle aged having the lowest score in propensity to plan. Income and education were positively associated with scores of propensity to plan. Respondents with more economic resources had higher scores in propensity to plan, such as those having checking accounts, saving accounts, 401(k) type plans, individual retirement accounts (IRAs) or other non-employer-sponsored retirement accounts, a home, credit card, or health insurance. Respondents who held a mortgage, home equity loan, or auto loan had higher scores and those who held unpaid medical bills, credit card debt, or high cost loans had lower scores in propensity to plan.

Table 3 presents the OLS regression results to examine socioeconomic differences in propensity to plan. The results are similar to those in Table 2 with several changes. When all socioeconomic factors were entered to one regression model, unlike the results in Table 2, several factors did not show associations at the significance level of 5\%, such as having dependent children, checking accounts, and health insurance. Two variables changed the direction of signs from positive to negative: mortgage and auto loan holdings. One variable, holding high cost loans, changed the sign from negative to positive. In the regression model, holding a high cost loan was positively associated with propensity to plan, which was unexpected. The results show that consumers with the characteristics of having a higher income, owning a home, and holding most types of financial assets were more likely to set long term goals. Most of these findings support H1 (Individuals with characteristics implying having higher levels of economic resources are associated with higher levels of propensity to plan).

Propensity to Plan and Financial Capability 
Table 4 presents correlation results between financial capability variables and propensity to plan. Propensity to plan was significantly correlated with all four financial capability variables (objective financial literacy, subjective financial literacy, desirable financial behavior, and perceived financial capability). Among them, the correlations with desirable financial behavior and subjective financial literacy were stronger, .494 and .386 , respectively, while correlations with perceived financial capability and objective financial literacy were weaker, .283 and .165 , respectively.

Table 5 presents results of multiple regressions on four financial capability variables that confirm the results in Table 4. In panel 1 of Table 5, two models for objective financial literacy were studied, one without and the other with the variable of propensity to plan. The results showed that propensity to plan contributed to the model by explaining $.1 \%$ more of the variance. In panel 2 of Table 5 on subjective financial literacy, propensity to plan explained $17.6 \%$ more of the variance. In panel 3 of Table 5 on desirable financial behavior, propensity to plan explained $9.5 \%$ more of the variance. In panel 4 of Table 5 on perceived financial capability, propensity to plan explained 3.8\% more of the variance. These findings support $\mathrm{H} 2$ (financial planning is positively associated with financial capability variables). In addition, comparing the standardized coefficients (beta values) of propensity to plan in Table 5, it appears that propensity to plan is most closely associated with desirable financial behavior, then subjective financial literacy and perceived financial capability, and least associated with objective financial literacy. Propensity to Plan and Financial Satisfaction

The correlation between propensity to plan and financial satisfaction was positive and significant (.463) (Table 4). The results of multiple regressions in Table 6 confirmed the findings in Table 4. Table 6 presents results of three models on financial satisfaction. Model 1 is the baseline model with socioeconomic factors as independent variables. Model 2 added four financial capability variables that explained 10.1\% more variance. Model 3 added the variable of propensity to plan that explained $2.2 \%$ more variance. The results show that, after controlling for socioeconomic and financial capability variables, propensity to plan still contributes uniquely to financial satisfaction, supporting H3 (financial planning is positively associated with financial satisfaction).

Table 6 also shows socioeconomic and financial capability factors associated with financial satisfaction. According to results of model 3 in Table 6, gender, marital status, age, income, and education show differences in financial satisfaction. Except for checking accounts, holding financial assets and products such as a savings account, 401(k) retirement plan, IRA or other investments, a home, health insurance, or credit card is positively associated 
with financial satisfaction. Holding most types of debts, such as mortgage, medical bill, credit card debt, or student loan, is negatively associated with financial satisfaction, except for home equity loan and high cost loan. Three of four financial capability variables were positively associated with financial satisfaction except for objective financial literacy. These findings are consistent with previous research.

\section{Discussion}

Using data from the 2015 U. S. National Financial Capability Study, this study examined factors associated with propensity to plan, the association between propensity to plan and financial capability factors, and the association between propensity to plan and financial satisfaction. The results suggest that propensity to plan is positively associated with economic resource levels. Also, propensity to plan is positively associated with four financial capability variables: objective financial literacy, subjective financial literacy, desirable financial behavior, and perceived financial capability. After controlling for socioeconomic and financial capability variables, propensity to plan is also positively associated with financial satisfaction, an indicator of subjective financial well-being.

Unlike most previous studies that used smaller, age-specific, or context-specific samples (e.g. Ameriks et al. 2003; Lusardi \& Mitchell 2007), this study used a nationally representative sample in the U.S. to demonstrate socioeconomic differences in propensity to plan. Results show that consumers who are willing to set long-term goals and strive to achieve them are different than others in gender, race, age, marital status, presence of children, working status, education, and income. Also, holding certain financial assets and debts may increase the score, while holding other debts may decrease the score of propensity to plan.

Propensity to plan is considered a desirable consumer behavior and a component of financial capability (Xiao \& O’Neill, 2016). The findings of this study show that propensity to plan is correlated with four financial capability indicators. The findings suggest that propensity to plan may result in desirable financial planning behavior and one positive behavior may be connected to various components of financial capability, suggesting that encouraging financial planning behavior may help improve consumer financial literacy and other desirable financial behaviors and these strategies may be used by consumer financial professionals to better serve their clients.

Financial satisfaction is a subjective measure of financial well-being. It measures consumer satisfaction about their financial status suggesting that they have adequate economic resources to support a comfortable life. It 
also indicates that they are happy about their financial status that is part of general happiness and an important component of quality of life. Previous research shows that propensity to plan is positively associated with objective measures of financial well-being such as wealth accumulation, retirement savings, and credit scores (Ameriks et al., 2003; Khwaja et al., 2007; Lee \& Kim, 2016; Lusardi \& Mitchell, 2007; Lynch et al., 2010). The findings of this study suggest that propensity to plan also makes a unique contribution to financial satisfaction, the subjective measure of financial well-being, consistent with the results from a Malaysian sample (Ali et al., 2015).

Limitations of this study should be recognized. First, the data is cross-sectional and cannot be used to test causality between propensity to plan and financial outcomes. Second, the data set is limited to residents of one country. Future research could use data from multiple countries and longitudinal data to explore the effects of propensity to plan on financial well-being over time. A third limitation of this study is that respondents' selfassessments of their financial well-being might not be the same as those by an independent third party (e.g., financial advisors). Future research may address this issue by using data that match consumer self-reported behaviors with actual behaviors observed with administrative and transaction data from financial service institutions.

Keeping limitations of this study in mind, the findings have implications for consumer financial service professionals to better serve their clients. The results about socioeconomic differences in propensity to plan may be used by consumer financial professionals to identify their clients' intention to plan and develop different strategies to work with them. For consumers who are more likely to engage in a long term planning, financial professionals may focus more on how help to them develop appropriate financial plans. For those who score low in propensity to plan, besides working with their financial plans, financial professionals may also need to explain the benefits of long-term planning and allow them to recognize the importance of goal-setting and goal attainment. Relevant research findings from psychology may be used to help clients better achieve their goals. Gollwitzer and Sheeran (2006) studied a specific type of advance plan called an "implementation intention" (e.g., "If situation $x$ arises, I will implement goal-directed response $\left.y^{\prime \prime}\right)$ and found implementation intentions positively affect goal attainment. This approach may be used with clients who lack motivation for long-term planning. Also information about socioeconomic differences in propensity to plan can be used for financial professionals when they promote their businesses and market their services to different types of clients.

Survey results suggest that financial planning is positively associated with indicators of financial capability. Since planning behavior is relatively straightforward and easy to understand, financial professionals should 
encourage their clients to engage in this behavior to contribute to other aspects of financial capability. Research findings from behavior science theories, such as the transtheoretical model of behavior change (TTM) (Xiao, O’Neill, Prochaska, Kerbel, Brennan, \& Bristow 2004) may be used to help clients develop positive behaviors that contribute to financial capability. It is also important to emphasize planning throughout the life cycle. This study found that the youngest respondents (aged 18-34) are more likely than older groups to be a planner. Perhaps people feel that they have less to plan for at an older age once some key life decisions like a family, career, and home purchase are made.

The findings of this study also suggest that propensity to plan contributes to subjective financial well-being. Financial professionals should emphasize the importance of long-term planning to their clients and point out the potential benefits of doing so. Financial professionals are a valuable resource to help consumers develop a habit of long-term planning and achieve important financial and lifestyle goals.

\section{References}

Agnew, S., \& Cameron-Agnew, T. (2015). The influence of consumer socialisation in the home on gender differences in financial literacy. International Journal of Consumer Studies, 39(6), 630-638.

Ahn, N., Ateca-Amestoy, V., \& Ugidos, A. (2014). Financial satisfaction from an intra-household perspective. Journal of Happiness Studies, 15(5), 1109-1123.

Ajzen, I. (1991). The theory of planned behavior. Organizational behavior and human decision processes, 50(2), 179-211.

Ali, A., Rahman, M. S. A., \& Bakar, A. (2015). Financial satisfaction and the influence of financial literacy in Malaysia. Social Indicators Research, 120(1), 137-156.

Alsemgeest, L. (2015). Arguments for and against financial literacy education: where to go from here?. International Journal of Consumer Studies, 39(2), 155-161.

Ameriks, J., Caplin, A., \& Leahy, J. (2003). Wealth accumulation and the propensity to plan. The Quarterly Journal of Economics, 118(3), 1007-1047.

Atkinson, A., McKay, S., Collard, S. \& Kempson, E. (2006). Levels of financial capability in the UK: Results of a baseline survey. Financial Services Authority, London.

Birkenmaier, J., Sherraden, M., \& Curley, J. (Eds.). (2013). Financial capability and asset development: Research, education, policy, and practice ( $1^{\text {st }}$ ed.). New York: Oxford University Press. 
Bryan, K. (2016). Less than half of U.S. households report good savings progress, according to $9^{\text {th }}$ annual America Saves Week survey. Washington, DC: Consumer Federation of America. Retrieved from http://www.americasavesweek.org/less-than-half-of-u-s-households-report-good-savings-progressaccording-to-9th-annual-america-saves-week-survey/.

CFPB. (2015). Measuring financial well-being: A guide to using the CFPB Financial Well-Being Scale. Washington, DC: Consumer Financial Protection Bureau.

de Rubio, A. R. (2015). Factors associated with household's planning horizons for making saving and spending decisions. Family and Consumer Sciences Research Journal. 43(3), 284-292.

Diener, E., \& Biswas-Diener, R. (2002). Will money increase subjective well-being?. Social indicators research, 57(2), 119-169.

Drever, A. I., Odders-White, E., Kalish, C. W., Else-Quest, N. M., Hoagland, E. M., \& Nelms, E. N. (2015). Foundations of financial well-being: Insights into the role of executive function, financial socialization, and experience-based learning in childhood and youth. Journal of Consumer Affairs, 49(1), 13-38.

Ferrer-i-Carbonell, A., \& Gërxhani, K. (2011). Financial Satisfaction and (in) formal Sector in a Transition Country. Social Indicators Research, 102(2), 315-331.

Financial health consumer segments (2015). Chicago, IL: Center for Financial Services Innovation. Retrieved from http://www.cfsinnovation.com/financial-health-segments.

Gollwitzer, P. M. \& Sheeran, P. (2006). Implementation intentions and goal achievement: a meta-analysis of effects and processes. Advances in Experimental Social Psychology, 38, 69-119.

Gollwitzer, P. M. (1996). The volitional benefits of planning. In J. Bargh \& P. Gollwitzer, eds. The psychology of action: Linking cognition and motivation to behavior (pp. 287-312). New York: Guilford.

Gollwitzer, P. M. (1999). Implementation intentions: strong effects of simple plans. American psychologist, 54(7), 493-503.

Grable, J. E., Cupples, S., Fernatt, F., \& Anderson, N. (2013). Evaluating the link between perceived income adequacy and financial satisfaction: A resource deficit hypothesis approach. Social Indicators Research, 114(3), 1109-1124.

Gutman, A., Garon, T., Hogarth, J., \& Schneider, R. (2016). Understanding and improving consumer financial health in America. Chicago, IL: Center for Financial Services Innovation. Retrieved from 
https://www.metlife.com/assets/cao/foundation/understanding-and-improving-consumer-financial-healthin-america.pdf.

Hansen, T., Slagsvold, B., \& Moum, T. (2008). Financial satisfaction in old age: a satisfaction paradox or a result of accumulated wealth? Social Indicators Research, 89(2), 323-347.

Hsieh, C. M. (2004). Income and financial satisfaction among older adults in the United States. Social Indicators Research, 66(3), 249-266.

Huston, S. (2010). Measuring financial literacy. Journal of Consumer Affairs, 44, 296-316.

Joo, S. H., \& Grable, J. E. (2004). An exploratory framework of the determinants of financial satisfaction. Journal of family and economic Issues, 25(1), 25-50.

Kageyama, J., \& Matsuura, T. (2016). The financial burden of having children and fertility differentials across development and life stages: Evidence from satisfaction data. Journal of Happiness Studies, 1-26.

Khwaja, A., Silverman, D., Sloan, F., \& Wang, Y. (2007). Smoking, wealth accumulation and the propensity to plan. Economics Letters, 94(1), 96-103.

Lee, J. M., \& Kim, K. T. (2016). The role of propensity to plan on retirement savings and asset accumulation. Family and Consumer Sciences Research Journal, 45(1), 34-48.

Lin, J. T. Bumcrot, C., Ulicny, T., Lusardi, A., Mottola, G., Kieffer, C., \& Walsh, G. (2016). Financial capability in the United States 2016. Washington, DC: FINRA Investor Education Foundation.

Lusardi, A. \& Mitchell, O.S. (2007). Baby boomer retirement security: The roles of planning, financial literacy, and housing wealth. Journal of Monetary Economics, 54(1), 205-224.

Lusardi, A. \& Mitchell, O.S. (2008). Planning and financial literacy: How do women fare? American Economic Review, 92(20, 413-417.

Lusardi, A., \& Mitchell, O. S. (2014). The economic importance of financial literacy: Theory and evidence. Journal of Economic Literature, 52(1), 5-44.

Lynch, J. G., Netemeyer, R.G., Spiller, S.A., \& Zammit, A. (2010). A generalizable scale of propensity to plan: The long and the short of planning for time and money. Journal of Consumer Research, 37, 108-128.

Michalos, A. C., \& Orlando, J. A. (2006). A note on student quality of life. Social Indicators Research, 79, 51-59.

Murendo, C., \& Mutsonziwa, K. (2017). Financial literacy and savings decisions by adult financial consumers in zimbabwe. International Journal of Consumer Studies, 41, 95-103. 
Nicolini, G., Cude, B. J., \& Chatterjee, S. (2013). Financial literacy: a comparative study across four countries. International Journal of Consumer Studies, 37(6), 689-705.

O’Neill, B., Xiao, J. J., \& Ensle, K. (2016). Propensity to plan: A key to health and wealth? Journal of Financial Planning, 29(3), 42-50.

Plagnol, A. C. (2011). Financial satisfaction over the life course: The influence of assets and liabilities. Journal of Economic Psychology, 32(1), 45-64.

Ratcliffe, J. (2015). Four elements define personal financial well-being. Washington, DC: Consumer Financial Protection Bureau. Retrieved from http://www.consumerfinance.gov/about-us/blog/four-elements-definepersonal-financial-well-being/.

Report reveals more than half of Americans are not financially healthy (2015). Chicago, IL: Center for Financial Services Innovation. Retrieved from http://www.cfsinnovation.com/Press-Releases/Report-Reveals-Morethan-Half-of-Americans-Are-Not.

Riitsalu, L., \& Põder, K. (2016). A glimpse of the complexity of factors that influence financial literacy. International Journal of Consumer Studies, 40(6), 722-731.

Robb, C. A., Babiarz, P., Woodyard, A., \& Seay, M. C. (2015). Bounded rationality and use of alternative financial services. Journal of Consumer Affairs, 49(2), 407-435.

Robb, C. \& Woodyard, A. (2011) Financial knowledge and best practice behavior. Journal of Financial Counseling and Planning, 22, 60-70.

Sherraden, M. S., \& Grinstein-Weiss, M. (2015). Creating financial capability in the next generation: An introduction to the special issue. Journal of Consumer Affairs, 49(1), 1-12.

Vera-Toscano, E., Ateca-Amestoy, V., \& Serrano-Del-Rosal, R. (2006). Building financial satisfaction. Social Indicators Research, 77(2), 211-243.

Xiao, J. J., \& O’Neill, B. (2016). Consumer financial education and financial capability. International Journal of Consumer Studies, 40(6), 712-721.

Xiao, J. J., \& Porto, N. (2017). Financial education and financial satisfaction: Financial literacy, behavior, and capability as mediators. International Journal of Bank Marketing, 35(5), 805-817.

Xiao, J. J., Chen, C., \& Chen, F. (2014). Consumer financial capability and financial satisfaction. Social Indicators Research, 118(1), 415-432. 
Xiao, J. J., Chen, C., \& Sun, L. (2015). Age differences in consumer financial capability. International Journal of Consumer Studies, 39(4), 387-395.

Xiao, J. J., O’Neill, B., Prochaska, J., Kerbel, C, Brennan, P., \& Bristow, B. (2004). A consumer education program based on the Transtheoretical Model of Change. International Journal of Consumer Studies, 28(1), 55-65.

Xiao, J. J., Tang, C., \& Shim, S. (2009). Acting for happiness: Financial behavior and life satisfaction of college students. Social Indicators Research, 92(1), 53-68. 
Table 1: Variable Specifications

\begin{tabular}{|c|c|c|}
\hline Variable name & Variable label & Attribute \\
\hline & Propensity to plan & \\
\hline \multirow[t]{2}{*}{$\mathrm{J} 33$} & Propensity to plan & $\begin{array}{l}\text { The original question "I set long term financial goals and } \\
\text { strive to achieve them" on a scale of 1-strongly disagree to } \\
7 \text {-strongly agree. }\end{array}$ \\
\hline & Financial capability & \\
\hline $\begin{array}{l}\operatorname{Sum}(\mathrm{m} 6, \mathrm{~m} 7 \\
\mathrm{m} 8, \mathrm{~m} 31, \mathrm{~m} 9 \\
\mathrm{~m} 10)\end{array}$ & Objective financial literacy & $\begin{array}{l}0-6 \text {, the sum of correct numbers for financial literacy } \\
\text { questions. The original financial literacy variables (m6- } \\
\text { m10) were recoded to binary variables in which } 1=\text { correct } \\
\text { answer, } 0=\text { otherwise and then the new variables were } \\
\text { summed to form the score. These questions asked financial } \\
\text { knowledge about interest }(\mathrm{m} 6) \text {, inflation }(\mathrm{m} 7) \text {, bond }(\mathrm{m} 8) \text {, } \\
\text { time value of money (m31), mortgage }(\mathrm{m} 9) \text {, and stock } \\
(\mathrm{m} 10) \text {. More details about these questions can be found at } \\
\text { Lin et al. (2016). }\end{array}$ \\
\hline \multirow[t]{2}{*}{ M4 } & Subjective financial literacy & $\begin{array}{l}\text { The question is "On a scale from } 1 \text { to } 7 \text {, where } 1 \text { means } \\
\text { very low and } 7 \text { means very high, how would you assess } \\
\text { your overall financial knowledge?" } 1 \text {-very low, } 7 \text {-very } \\
\text { high. }\end{array}$ \\
\hline & Desirable financial behavior & $\begin{array}{l}\text { The sum of } 4 \text { dummy variables of desirable financial } \\
\text { behaviors, which are spending within income (J3), saving } \\
\text { for emergency (J5), budgeting (J31), and calculating } \\
\text { retirement needs (J8 and J9), in which variable names } \\
\text { from the original data set are in parentheses. All of these } \\
\text { variables are appropriately recoded to dummy variables } \\
(1=\text { performed the behavior, } 0=\text { otherwise) before summing } \\
\text { them up to this variable. }\end{array}$ \\
\hline \multirow[t]{2}{*}{ M1_1 } & Perceived financial capability & $\begin{array}{l}\text { The question is "I am good at dealing with day-to-day } \\
\text { financial matters, such as checking accounts, credit and } \\
\text { debit cards, and tracking expenses," 1-strongly disagree, 7- } \\
\text { strongly agree. }\end{array}$ \\
\hline & Financial Satisfaction & \\
\hline \multirow[t]{2}{*}{$\mathrm{J} 1$} & Financial satisfaction & $\begin{array}{l}\text { The original question "Overall, thinking of your assets, } \\
\text { debts and savings, how satisfied are you with your current } \\
\text { personal financial condition? Please use a 10-point scale, } \\
\text { where } 1 \text { means 'Not At All Satisfied' and } 10 \text { means } \\
\text { 'Extremely Satisfied."' }\end{array}$ \\
\hline & $\begin{array}{l}\text { Demographic and financial } \\
\text { variables }\end{array}$ & \\
\hline A3 & Being male (vs. female) & Recoded, $1=$ male, $0=$ female \\
\hline A4a_new_w & Being White & Recoded, $1=$ white, $0=$ non white \\
\hline A6 & Being married & Recoded, $1=$ married, $0=$ not married \\
\hline A11 & Having dependent children & Recoded, $1=$ yes, $0=$ no \\
\hline A9 & Working & Recoded, $1=$ yes, $0=$ no \\
\hline A3Ar_w & Age group & $\begin{array}{l}\text { Recoded to } 3 \text { age groups: } \\
1-18-34 \\
2-35-64 \\
3-65+\end{array}$ \\
\hline A5 & Education level & $\begin{array}{l}\text { Recoded to } 3 \text { education levels: } \\
\text { 1-Did not complete high school; High school graduate - } \\
\text { regular high school diploma; High school graduate- } \\
\text { GED or alternative credential } \\
\text { 2-Some college, no degree; Associate's degree } \\
\text { 3-Bachelor's degree; Post graduate degree }\end{array}$ \\
\hline
\end{tabular}




$\begin{array}{ll}\text { A8 } & \text { Income level } \\ & \\ \text { B1 } & \\ \text { B2 } & \text { Have checking } \\ \text { C1 } & \text { Have saving etc. } \\ \text { C4 } & \text { Have 401(k) } \\ \text { Ea_1 } & \text { Have IRA etc. } \\ \text { E7 } & \text { Own home } \\ \text { E8 } & \text { Have mortgage } \\ \text { G1 } & \text { Have home equity loan } \\ \text { G2 } & \text { Have auto loan } \\ \text { H1 } & \text { Have medical bill } \\ \text { F1 } & \text { Have health insurance } \\ \text { F2_2 } & \text { Have credit card } \\ \text { G30 } & \text { Have credit card debt } \\ \text { G25 } & \text { Have student loan } \\ & \text { Have high cost loan }\end{array}$

Recoded to 3 income levels:

1-0 to less than $\$ 25,000$

2 -At least $\$ 25,000$ but less than $\$ 75,000$

3 -At least $\$ 75,000$ and more

Recoded, $1=$ yes, $0=$ no

Recoded, $1=$ yes, $0=$ no

Recoded, $1=$ yes, $0=$ no

Recoded, $1=$ yes, $0=$ no

Recoded, $1=$ yes, $0=$ no

Recoded, $1=$ yes, $0=$ no

Recoded, $1=$ yes, $0=$ no

Recoded, $1=$ yes, $0=$ no

Recoded, $1=$ yes, $0=$ no

Recoded, $1=$ yes, $0=$ no

Recoded, $1=$ yes, $0=$ no

Recoded, $1=$ yes, $0=$ no

Recoded, $1=$ yes, $0=$ no

The respondents are asked if they have used several high cost loans such as auto title loan (G25_1), payday loan (G25_2), pawn shop (G25_4), and rent-to-own store (G25_5). If they used at least once to any of these loans, it is coded as 1, 0 otherwise.

Note: Variable names are from the codebook of the 2015 National Financial Capability Study. 
Table 2 Propensity to Plan by Socioeconomic Variables $(\mathrm{N}=27,160)$

\begin{tabular}{|c|c|c|c|}
\hline & & Mean & $\begin{array}{l}\text { One-way } \\
\text { ANOVA } \\
\text { p value }\end{array}$ \\
\hline Total & & 4.86 & \\
\hline \multirow[t]{2}{*}{ Gender } & female & 4.73 & $<.001$ \\
\hline & male & 5.02 & \\
\hline \multirow[t]{2}{*}{ Race } & nonwhite & 4.96 & $<.001$ \\
\hline & white & 4.83 & \\
\hline \multirow[t]{2}{*}{ Marital status } & not married & 4.57 & $<.001$ \\
\hline & married & 5.05 & \\
\hline \multirow{2}{*}{$\begin{array}{l}\text { Have dependent } \\
\text { children }\end{array}$} & no & 4.81 & $<.001$ \\
\hline & yes & 4.95 & \\
\hline \multirow[t]{2}{*}{ Working } & no & 4.61 & $<.001$ \\
\hline & yes & 5.06 & \\
\hline \multirow[t]{3}{*}{ Age } & $18-34$ & 5.08 & $<.001$ \\
\hline & $35-64$ & 4.73 & \\
\hline & 65 or older & 4.90 & \\
\hline \multirow[t]{3}{*}{ Education } & High school & 4.42 & $<.001$ \\
\hline & Some college & 4.74 & \\
\hline & $\begin{array}{l}\text { 4-year college } \\
\text { degree or higher }\end{array}$ & 5.29 & \\
\hline \multirow[t]{3}{*}{ Income } & $0-\$ 24999$ & 4.10 & $<.001$ \\
\hline & $\$ 25000-\$ 74999$ & 4.80 & \\
\hline & $\$ 75000$ or higher & 5.48 & \\
\hline \multirow[t]{2}{*}{ Have checking } & no & 4.12 & $<.001$ \\
\hline & yes & 4.92 & \\
\hline \multirow[t]{2}{*}{ Have saving } & no & 4.05 & $<.001$ \\
\hline & yes & 5.10 & \\
\hline \multirow[t]{2}{*}{ Have 401(k) } & no & 4.39 & $<.001$ \\
\hline & yes & 5.22 & \\
\hline Have IRA, etc. & no & 4.46 & $<.001$ \\
\hline
\end{tabular}




\begin{tabular}{|c|c|c|c|}
\hline & yes & 5.62 & \\
\hline \multirow[t]{2}{*}{ Own home } & no & 4.43 & $<.001$ \\
\hline & yes & 5.12 & \\
\hline \multirow[t]{2}{*}{ Have mortgage } & no & 4.75 & $<.001$ \\
\hline & yes & 5.06 & \\
\hline \multirow{2}{*}{$\begin{array}{l}\text { Have home equity } \\
\text { loan }\end{array}$} & no & 4.81 & $<.001$ \\
\hline & yes & 5.33 & \\
\hline \multirow[t]{2}{*}{ Have auto loan } & no & 4.83 & $<.001$ \\
\hline & Yes & 4.92 & \\
\hline \multirow{2}{*}{$\begin{array}{l}\text { Have unpaid medical } \\
\text { bill }\end{array}$} & no & 5.00 & $<.001$ \\
\hline & Yes & 4.32 & \\
\hline \multirow{2}{*}{$\begin{array}{l}\text { Have health } \\
\text { insurance }\end{array}$} & no & 4.37 & $<.001$ \\
\hline & yes & 4.92 & \\
\hline \multirow[t]{2}{*}{ Have credit card } & no & 4.07 & $<.001$ \\
\hline & yes & 5.07 & \\
\hline \multirow[t]{2}{*}{ Have credit card debt } & no & 4.97 & $<.001$ \\
\hline & yes & 4.68 & \\
\hline \multirow[t]{2}{*}{ Have student loan } & no & 4.86 & .974 \\
\hline & yes & 4.86 & \\
\hline \multirow[t]{2}{*}{ Have high cost loan } & no & 4.96 & $<.001$ \\
\hline & yes & 4.69 & \\
\hline
\end{tabular}

Notes: One-way ANOVA were conducted. For variables with three attributes such as age, education, and income, post hoc tests were conducted and the results were statistically different between subgroups among these variables. 
Table 3 OLS Regression results on Propensity to Plan

\begin{tabular}{|c|c|c|c|}
\hline & B & Beta & $\mathrm{p}$ \\
\hline Constant & 3.972 & & $<.001$ \\
\hline Male & .092 & .025 & $<.001$ \\
\hline White & -.265 & -.066 & $<.001$ \\
\hline Married/cohabiting & .074 & .020 & .002 \\
\hline Have dependent children & .039 & .010 & .091 \\
\hline Working & .102 & .028 & $<.001$ \\
\hline Age 35-64 & -.655 & -.181 & $<.001$ \\
\hline Age 65 and older & -.725 & -.156 & $<.001$ \\
\hline Income $25 \mathrm{k}-75 \mathrm{k}$ & .232 & .064 & $<.001$ \\
\hline Income $75 \mathrm{k}$ or more & .518 & .134 & $<.001$ \\
\hline Education - some college & .089 & .024 & .001 \\
\hline Education - bachelor degree or higher & .140 & .037 & $<.001$ \\
\hline Have checking & -.004 & -.001 & .914 \\
\hline Have saving etc. & .416 & .096 & $<.001$ \\
\hline Have $401(\mathrm{k})$ & .225 & .062 & $<.001$ \\
\hline Have IRA etc. & .678 & .178 & $<.001$ \\
\hline Own home & .366 & .098 & $<.001$ \\
\hline Have mortgage & -.234 & -.062 & $<.001$ \\
\hline Have home equity loan & .089 & .015 & .011 \\
\hline Have auto loan & -.104 & -.027 & $<.001$ \\
\hline Have medical bill & -.325 & -.072 & $<.001$ \\
\hline Have health insurance & .059 & .010 & .076 \\
\hline Have credit card & .493 & .110 & $<.001$ \\
\hline Have credit card debt & -.438 & -.117 & $<.001$ \\
\hline Have student loan & -.028 & -.007 & .255 \\
\hline Have high cost loan & .135 & .032 & $<.001$ \\
\hline
\end{tabular}

Notes: reference categories are age under 25 , income under $\$ 25,000$, and education of high school or lower. OR refers to odds ratio. $\mathrm{N}=27564$. -2 Log likelihood $=32435.194$. Cox \& Snell R Square $=.166$. Nagelkerke R Square $=.223$. Overall percentage of correct predictions $=68.7 \%$. 
Table 4 Correlations between Financial Capability Variables and Financial Satisfaction by Propensity to Plan

\begin{tabular}{lcrrrr}
\hline & $\begin{array}{c}\text { Propensity } \\
\text { to plan }\end{array}$ & $\begin{array}{c}\text { Objective } \\
\text { literacy }\end{array}$ & $\begin{array}{c}\text { Subjective } \\
\text { literacy }\end{array}$ & $\begin{array}{c}\text { Perceived } \\
\text { capability }\end{array}$ & $\begin{array}{c}\text { Desirable } \\
\text { behavior }\end{array}$ \\
\hline Objective literacy & $.165^{* *}$ & & & & \\
Subjective literacy & $.386^{* *}$ & $.225^{* *}$ & & & \\
Perceived capability & $.283^{* *}$ & $.267^{* *}$ & $.449^{* *}$ & & \\
Desirable behavior & $.494^{* *}$ & $.280^{* *}$ & $.334^{* *}$ & $.306^{* *}$ & \\
Financial satisfaction & $.463^{* *}$ & $.125^{* *}$ & $.418^{* *}$ & $.274^{* *}$ & $.444^{* *}$ \\
\hline
\end{tabular}

** $\mathrm{p}<.01$ 
Table 5 OLS Regression Results on Financial Capability Variables

\begin{tabular}{|c|c|c|c|c|c|}
\hline & \multirow{2}{*}{$\begin{array}{r}\text { Model } 1 \\
\text { B }\end{array}$} & \multicolumn{3}{|c|}{ Model 2} & \\
\hline & & beta & $\mathrm{B}$ & beta & \\
\hline \multicolumn{6}{|c|}{ 1. $\mathrm{DV}=$ Objective financial literacy } \\
\hline Control variables & yes & & yes & & \\
\hline Propensity to plan & & & .027 & .029 & $* * *$ \\
\hline $\mathrm{R}^{2}$ change & .276 & & .001 & & \\
\hline F change & 413 & & 25 & & \\
\hline$p$ of $R^{2}$ change & $<.001$ & & $<.001$ & & \\
\hline \multicolumn{6}{|c|}{ 2. $\mathrm{DV}=$ Subjective financial literacy } \\
\hline Control variables & yes & & yes & & \\
\hline Propensity to plan & & & .205 & .309 & $* * *$ \\
\hline $\mathrm{R}^{2}$ change & .140 & & .176 & & \\
\hline F change & 173 & & 2570 & & \\
\hline $\mathrm{p}$ of $\mathrm{R}^{2}$ change & $<.001$ & & $<.001$ & & \\
\hline \multicolumn{6}{|c|}{ 3. $\mathrm{DV}=$ Desirable financial behavior } \\
\hline Control variables & yes & & yes & & \\
\hline Propensity to plan & & & .236 & .346 & $* * *$ \\
\hline $\mathrm{R}^{2}$ change & .275 & & .095 & & \\
\hline F change & 412 & & 4085 & & \\
\hline $\mathrm{p}$ of $\mathrm{R}^{2}$ change & $<.001$ & & $<.001$ & & \\
\hline \multicolumn{6}{|c|}{ 4. $\mathrm{DV}=$ Perceived financial capability } \\
\hline Control variables & yes & & yes & & \\
\hline Propensity to plan & & & .169 & .219 & $* * *$ \\
\hline $\mathrm{R}^{2}$ change & .139 & & .038 & & \\
\hline F change & 173 & & 1248 & & \\
\hline $\mathrm{p}$ of $\mathrm{R}^{2}$ change & $<.001$ & & $<.001$ & & \\
\hline
\end{tabular}

Note: $* * * \mathrm{p}<.001$. For each of the above models, control variables include following binary ones: male, white, married/cohabiting, having dependent children, working, age 35-64, age 65 or older, income $25 \mathrm{k}-75 \mathrm{k}$, income $75 \mathrm{k}$ or more, education some college, education bachelor or higher, having checking, saving etc., 401(k), IRA etc., home, mortgage, home equity loan, auto loan, medical bill, health insurance, credit card, credit card debt, student loan, and high cost loan. Full tables are available from the authors upon requests. 
Table 6 OLS Regression Results on Financial Satisfaction

\begin{tabular}{|c|c|c|c|c|c|c|c|c|c|}
\hline & $\begin{array}{c}\text { Model } \\
\text { B } \\
\end{array}$ & $\begin{array}{c}1 \\
\text { beta } \\
\end{array}$ & $\mathrm{p}$ & $\begin{array}{c}\text { Mode } \\
1 \\
\text { B } \\
\end{array}$ & $\begin{array}{c}2 \\
\text { beta }\end{array}$ & $\mathrm{p}$ & $\begin{array}{c}\text { Mod } \\
\text { el } \\
\text { B } \\
\end{array}$ & beta & $\mathrm{p}$ \\
\hline Constant & 3.985 & & $<.001$ & 1.316 & & $<.001$ & .779 & & $<.001$ \\
\hline Male & .386 & .070 & $<.001$ & .395 & .072 & $<.001$ & .386 & .070 & $<.001$ \\
\hline White & -.236 & -.039 & $<.001$ & -.085 & -.014 & .005 & -.027 & -.004 & .367 \\
\hline Married/cohabiting & .100 & .018 & .004 & .082 & .015 & .010 & .067 & .012 & .033 \\
\hline Have dependent children & .080 & .014 & .015 & .002 & .000 & .954 & -.001 & .000 & .969 \\
\hline Working & .032 & .006 & .332 & -.011 & -.002 & .715 & -.031 & -.006 & .298 \\
\hline Age $35-64$ & -.735 & -.134 & $<.001$ & -.607 & -.111 & $<.001$ & -.437 & -.080 & $<.001$ \\
\hline Age 65 or older & -.179 & -.026 & $<.001$ & -.167 & -.024 & $<.001$ & .051 & .007 & .284 \\
\hline Income $25 \mathrm{k}-75 \mathrm{k}$ & .682 & .124 & $<.001$ & .581 & .106 & $<.001$ & .543 & .099 & $<.001$ \\
\hline Income $75 \mathrm{k}$ or more & 1.276 & .218 & $<.001$ & 1.084 & .185 & $<.001$ & .997 & .171 & $<.001$ \\
\hline Education some college & -.128 & -.023 & $<.001$ & -.113 & -.020 & .001 & -.120 & -.021 & $<.001$ \\
\hline $\begin{array}{l}\text { Education bachelor or } \\
\text { higher }\end{array}$ & -.134 & -.024 & $<.001$ & -.074 & -.013 & .059 & -.085 & -.015 & .027 \\
\hline Have checking & -.210 & -.020 & .001 & -.283 & -.026 & $<.001$ & -.245 & -.023 & $<.001$ \\
\hline Have saving etc. & .466 & .070 & $<.001$ & .268 & .040 & $<.001$ & .212 & .032 & $<.001$ \\
\hline Have $401(\mathrm{k})$ & .306 & .055 & $<.001$ & .212 & .038 & $<.001$ & .191 & .034 & $<.001$ \\
\hline Have IRA etc. & .930 & .162 & $<.001$ & .589 & .103 & $<.001$ & .504 & .088 & $<.001$ \\
\hline Own home & .856 & .151 & $<.001$ & .618 & .109 & $<.001$ & .566 & .100 & $<.001$ \\
\hline Have mortgage & -.562 & -.099 & $<.001$ & -.450 & -.080 & $<.001$ & -.406 & -.072 & $<.001$ \\
\hline Have home equity loan & .291 & .032 & $<.001$ & .174 & .019 & $<.001$ & .163 & .018 & $<.001$ \\
\hline Have auto loan & -.074 & -.013 & .024 & -.060 & -.010 & .049 & -.039 & -.007 & .194 \\
\hline Have medical bill & -.786 & -.115 & $<.001$ & -.678 & -.099 & $<.001$ & -.625 & -.091 & $<.001$ \\
\hline Have health insurance & .220 & .025 & $<.001$ & .222 & .025 & $<.001$ & .209 & .023 & $<.001$ \\
\hline Have credit card & 1.066 & .155 & $<.001$ & .787 & .115 & $<.001$ & .721 & .105 & $<.001$ \\
\hline Have credit card debt & -1.064 & -.188 & $<.001$ & -.825 & -.146 & $<.001$ & -.766 & -.135 & $<.001$ \\
\hline Have student loan & -.329 & -.054 & $<.001$ & -.282 & -.046 & $<.001$ & -.289 & -.047 & $<.001$ \\
\hline Have high cost loan & .265 & .041 & $<.001$ & .115 & .018 & .001 & .098 & .015 & .003 \\
\hline Objective financial literacy & & & & -.223 & -.134 & $<.001$ & -.216 & -.129 & $<.001$ \\
\hline Subjective financial literacy & & & & .527 & .229 & $<.001$ & .443 & .192 & $<.001$ \\
\hline Desirable financial behavior & & & & .438 & .197 & $<.001$ & .304 & .137 & $<.001$ \\
\hline Perceived fin. capability & & & & .070 & .035 & $<.001$ & .042 & .021 & $<.001$ \\
\hline Propensity to plan & & & & & & & .282 & .186 & $<.001$ \\
\hline $\mathrm{R}^{2}$ change & .308 & & & .101 & & & .022 & & \\
\hline F change & 469 & & & 1131 & & & 1031 & & \\
\hline$p$ of $R^{2}$ change & $<.001$ & & & $<.001$ & & & $\begin{array}{c}<.00 \\
1\end{array}$ & & \\
\hline
\end{tabular}

